\title{
Overwintering Viruliferous Frankliniella occidentalis (Thysanoptera: Thripidae) as an Infection Source of Tomato spotted wilt virus in Green Pepper Fields
}

\author{
Shinichiro Okazaki, Oita Prefectural Agriculture, Forestry and Fisheries Research Center, Usa, Oita 872-0103, \\ Japan; Mitsuru Okuda, National Agricultural Research Center for Kyushu Okinawa Region, Koshi, Kumamoto \\ 861-1192, Japan; Kazuhiro Komi, Kochi Agricultural Research Center, Nankoku, Kochi 783-0023, Japan; Hideaki \\ Yoshimatsu, Oita Prefectural Agriculture, Forestry and Fisheries Research Center, Usa, Oita 872-0103, Japan; and \\ Toru Iwanami, National Agricultural Research Center for Kyushu Okinawa Region, Koshi, Kumamoto 861-1192, \\ Japan
}

\begin{abstract}
Okazaki, S., Okuda, M., Komi, K., Yoshimatsu, H., and Iwanami, T. 2007. Overwintering viruliferous Frankliniella occidentalis (Thysanoptera: Thripidae) as an infection source of Tomato spotted wilt virus in green pepper fields. Plant Dis. 91:842-846.

Populations of overwintering viruliferous Frankliniella occidentalis were evaluated in Tomato spotted wilt virus (TSWV)-affected green pepper fields in Bungo-Ohno City, Oita Prefecture, Japan. A survey of TSWV-infected weeds showed that the incidence of infection was low in weeds. Stellaria aquatica was infected frequently; however, the infections were considered secondary cases since $S$. aquatica appeared in the fields around late February to early March. In contrast, TSWV was frequently detected from green pepper fruits until they rotted. F. occidentalis primarily inhabited and reproduced on the green pepper fruits and moved to Lamium amplexicaule when the fruits rotted and subsequently spread to other weed species as young shoots or flowers appeared. The flying activity level of $F$. occidentalis rose in late February, and viruliferous $F$. occidentalis transmitted TSWV to green pepper plants. We concluded that TSWV-infected green pepper fruits discarded in greenhouses and fields are the major source of infection.
\end{abstract}

Additional keywords: sticky trap

Tomato spotted wilt virus (TSWV) is a serious pathogen affecting a wide range of vegetable and ornamental crops around the world. The spotted wilt disease caused by TSWV was first reported on tomato plant in Australia $(3,19)$. In Japan, TSWV was first isolated from Dahlia pinnata in 1965 (20) and subsequently isolated from tomato (10), green pepper, and many other ornamental crops (9). TSWV rapidly spread throughout Japan in the late 1990s and became one of the most serious pathogen of vegetables and ornamental crops grown in greenhouses.

TSWV is the type species of the genus Tospovirus in the family Bunyaviridae (17). This pathogen is transmitted by at least seven thrips species (16) that are members of the family Thripidae. Frankliniella occidentalis (Pergande) was first

Corresponding author: M. Okuda

E-mail: mokuda@affrc.go.jp

Current address of T. Iwanami: National Institute of Fruit Tree Science, Tsukuba, Ibaraki 305-8605, Japan.

Accepted for publication 23 February 2007.

doi:10.1094/PDIS-91-7-0842

(C) 2007 The American Phytopathological Society found in 1992 and currently is one of the common species in greenhouses in Japan. Since the distribution of $F$. occidentalis and epidemics of TSWV disease are correlated, it is considered that $F$. occidentalis is involved in the prevalence of TSWVinduced diseases in Japan. The life cycle of F. occidentalis is 12.1 days at $25.0^{\circ} \mathrm{C}(8)$. In most cases, its population peaks in the summer. However, reproduction is hampered above $35^{\circ} \mathrm{C}$. F . occidentalis can survive for 30 days at $-5^{\circ} \mathrm{C}$ under experimental conditions (7). Field experiments in the southeastern United States revealed that $F$. occidentalis can overwinter in the fields and reproduce throughout the winter $(1,4,5)$.

Thrips and weeds play important roles in the infection cycles of TSWV in fields. In particular, thrips on TSWV-infected weeds appeared to cause primary infection in the spring. McPherson et al. (13) surveyed the presence of viruliferous thrips on weeds in TSWV-infected tobacco fields during the winter and revealed that several weed species were infected with TSWV and $F$. occidentalis and $F$. fusca on weeds could be potential vectors in tobacco fields. Similarly, Groves et al. (6) revealed that three annual weed species were infected with TSWV from winter to spring and were potential sources of infection.
In Bungo-Ohno City, Oita Prefecture, Japan, where green peppers are extensively cultivated from early spring to autumn, TSWV-induced diseases have been common since the first outbreak in 1998. Economic loss due to TSWV-induced diseases in this city was more than $\$ 180,000$ a year. In this area, $F$. occidentalis is the dominant thrips species in greenhouses and is considered to be the major vector of TSWV. It would be an effective control measure if we could break the infection cycle during the winter; however, the ecological characteristics of overwintering thrips and weeds in this area had been unclear. The objectives of this study were to estimate the seasonal transition of the infection potential by surveying populations of overwintering viruliferous $F$. occidentalis around green pepper greenhouses and investigating the incidence of TSWV infection in weeds in the winter.

\section{MATERIALS AND METHODS}

Survey locations. Two greenhouses in Koshoji (survey location A, [SLA]), Kamizono (SLB), and one open field, where a greenhouse had been assembled in the summer in Bungo-Ohno City in Kokuragi (SLC), were chosen for this study. Green peppers were grown in these greenhouses from the end of March to November, and TSWV had been detected from green pepper plants and F. occidentalis during the growing periods in 2002 and 2003, respectively (unpublished data). A green pepper greenhouse in Katashima that was not affected by TSWV (SLH) was chosen as a negative control.

Field survey of TSWV infection on weeds and green pepper fruits left in greenhouses. Weeds and green pepper fruits left at the survey locations were sampled in SLA, SLB, and SLC. TSWV infection was examined by reverse transcription-polymerase chain reaction (RTPCR). RNA extraction and RT-PCR were performed using ISOGEN (Nippon gene, Tokyo, Japan) and GeneAmp Gold RNA PCR kit (Applied Biosystems, Foster City, CA), respectively, according to the manufacturer's protocols. Reverse transcription of RNA was conducted for $30 \mathrm{~min}$ at $42^{\circ} \mathrm{C}$, and PCR was subsequently performed with 
40 cycles of $94^{\circ} \mathrm{C}$ for $30 \mathrm{sec}, 50^{\circ} \mathrm{C}$ for 30 sec, and extension at $72^{\circ} \mathrm{C}$ for 1 min using a primer set designed to detect the TSWV $N$ gene (TsN-5, 5' TTTAACACACTAAGCAAGCACA $3^{\prime}$, corresponding to nucleotides 1,899-1,920 of GenBank accession no. D00645; and, TsS3, 5' GCTCTAGAGCAATTGTGTCAATT 3 ', the reverse complement of nucleotides 2,916-2,899). RTPCR products were fractionated on $1 \%$ agarose gels and observed under UV light after staining with ethidium bromide (50 $\mu \mathrm{g} / \mathrm{ml})$.

Field survey of viruliferous $F$. occidentalis. Weeds and green pepper fruits left in the survey locations were sampled every 6 to 25 days from November 2002 to March 2003 in SLA, and from January 2003 to May 2004 in SLB and SLC. F. occidentalis adults were collected from the weeds and green pepper fruits, and TSWV was detected by double-antibody sandwich enzyme-linked immunosorbent assay (DAS-ELISA). TSWV-specific antibody and alkaline phosphatase conjugate antibody were obtained from the Japan Plant Protection Association (Tokyo). Absorbance values $\left(A_{405}\right)$ were measured with an Immuno Reader NJ-2001 (Inter Med, Roskilde, Denmark). Samples were considered positive if they showed values three times higher than the mean of healthy female $F$. occidentalis adults.

Transition of $F$. occidentalis populations in the field. To estimate the inhabitation pattern of $F$. occidentalis, seven weed species and green pepper fruits were collected every 6 to 15 days from 9 January to 21 April 2004 in SLC. F. occidentalis adults were collected from the samples. Larvae were grown by feeding with broad beans (18) to identify the species.

Survey of viruliferous $F$. occidentalis transition using sticky traps. Blue sticky

Table 1. Tomato spotted wilt virus infection on weeds and discarded green pepper fruits

\begin{tabular}{|c|c|c|c|}
\hline \multirow[b]{2}{*}{ Hosts } & \multicolumn{3}{|c|}{ Location $^{\text {a }}$} \\
\hline & SLA & SLB & SLC \\
\hline Discarded green pepper fruits & $11(11)^{\mathrm{b}}$ & $35(37)$ & $34(41)$ \\
\hline Artemisia princeps & $0(5)$ & $0(1)$ & $\ldots^{\mathrm{c}}$ \\
\hline Cerastium glomeratum & $0(1)$ & & $0(4)$ \\
\hline Conyza bonariensis/Conyza sumatrensis & $0(5)$ & $0(1)$ & $0(2)$ \\
\hline Corydalis incisa & $\ldots$ & $\ldots$ & $0(2)$ \\
\hline Galinsoga ciliata & $1(14)$ & $\ldots$ & $\ldots$ \\
\hline Gnaphalium japonicum & $0(10)$ & $\ldots$ & $\ldots$ \\
\hline Ixeris stolonifera & $0(3)$ & $\ldots$ & $\ldots$ \\
\hline Lamium amplexicaule & $\ldots$ & $1(7)$ & $0(4)$ \\
\hline Oxalis corniculata & $\ldots$ & $0(1)$ & $0(1)$ \\
\hline Plantago asiatica & $0(5)$ & $\ldots$ & $\ldots$ \\
\hline Portulaca oleracea & $0(1)$ & $\ldots$ & $\ldots$ \\
\hline Rorippa islandica & $0(2)$ & $\ldots$ & $\ldots$ \\
\hline Solanum nigrum & $1(18)$ & $0(4)$ & $\ldots$ \\
\hline Sonchus oleraceus & $0(1)$ & $0(1)$ & $\ldots$ \\
\hline Stellaria aquatica & $1(8)$ & $4(5)$ & $3(9)$ \\
\hline Veronica persica & $0(2)$ & $1(6)$ & $1(6)$ \\
\hline Vicia angustifolia & $0(2)$ & $0(3)$ & $\ldots$ \\
\hline Infection rate & $3.9 \%$ & $20.6 \%$ & $14.3 \%$ \\
\hline
\end{tabular}

traps (HORIVER, Arysta Life Science, Tokyo, Japan) were used to capture flying $F$. occidentalis in SLC. Three sticky traps were placed in each field approximately 30 $\mathrm{cm}$ high. Sticky traps were changed every 6 to 15 days from January 2003 to April 2004, and each adult insect was detached from the trap plate under microscope observation. Viruliferous $F$. occidentalis that was bonded on a sticky trap for 2 weeks can be distinctly differentiated from healthy ones by DAS-ELISA (K. Komi, M. Okuda, and T. Iwanami, unpublished data). Therefore, DAS-ELISA using TSWV-specific antibody and alkaline phosphatase conjugate antibody was conducted for each sample, and samples were considered viruliferous if $A_{405}$ is three times more than the mean of healthy $F$. occidentalis.

Evaluation of natural infection using seedling traps. To evaluate the natural infection of TSWV in Bungo-Ohno City, green pepper seedlings (cv. Sarara) were grown in 10-cm-diameter pots and placed in SLC. On 7 April 2004, 10 82-day-old seedlings were planted $50 \mathrm{~cm}$ apart in the corner of a field. The seedlings were collected on 18 May 2004. TSWV infection was examined by DAS-ELISA.

\section{RESULTS}

TSWV infection in weeds and green pepper fruits. Seventy-seven plants of 14 weed species, 29 plants of 9 species, and 28 plants of 7 species were sampled in SLA, SLB, and SLC, respectively, and RT-PCR tests revealed that 3.9, 20.6, and $14.3 \%$ of the plants were TSWV infected, respectively (Table 1). However, the infected species were limited. A relatively high proportion of Stellaria aquatica was infected with TSWV. In contrast, TSWV was frequently detected from green pepper fruits left at each location until the fruits rotted away.

Field survey of viruliferous $F$. occidentalis. A field survey in SLA revealed that $F$. occidentalis adults inhabited green pepper fruits discarded on the ground until

Table 2. Population and viruliferous proportion of adult Frankliniella occidentalis on weeds and discarded green pepper fruits in a greenhouse in Koshoji

\begin{tabular}{|c|c|c|c|c|c|c|c|c|c|c|}
\hline \multirow[b]{2}{*}{ Hosts } & \multicolumn{4}{|c|}{2002} & \multicolumn{6}{|c|}{2003} \\
\hline & $11 / 12$ & $11 / 26$ & $12 / 12$ & $12 / 24$ & $1 / 8$ & $1 / 23$ & $2 / 10$ & $2 / 25$ & 3/11 & $3 / 25$ \\
\hline Discarded green pepper fruits & $25(7)^{\mathrm{a}}$ & $39(14)$ & $3(2)$ & $19(3)$ & $35(18)$ & $9(4)$ & $4(4)$ & $* \mathrm{~b}$ & $*$ & * \\
\hline Solanum nigrum & $\ldots^{c}$ & $\ldots$ & $1(1)$ & $6(1)$ & $4(1)$ & $3(1)$ & & & $\ldots$ & \\
\hline Cerastium glomeratum & $\ldots$ & $\ldots$ & $9(3)$ & $\ldots$ & $\ldots$ & $\ldots$ & $0(0)$ & $2(2)$ & $\ldots$ & $0(0)$ \\
\hline Erigeron Canadensis & $\ldots$ & $\ldots$ & $\ldots$ & $\ldots$ & $3(0)$ & $\ldots$ & $\ldots$ & $6(3)$ & $4(2)$ & $\ldots$ \\
\hline Gnaphalium pensylvanicum & $\ldots$ & $\ldots$ & $\ldots$ & $\ldots$ & $\ldots$ & $38(15)$ & $\ldots$ & $9(3)$ & $\ldots$ & $\ldots$ \\
\hline Conyza sumatrensis & $\ldots$ & $\ldots$ & $\ldots$ & $\ldots$ & $\ldots$ & $\ldots$ & $4(1)$ & $\ldots$ & $\ldots$ & $\ldots$ \\
\hline Stellaria aquatica & $\ldots$ & $\ldots$ & $\ldots$ & $\ldots$ & $\ldots$ & $\ldots$ & $6(1)$ & $0(0)$ & $7(5)$ & $\ldots$ \\
\hline Gnaphalium japonicum & $\ldots$ & $\ldots$ & $\ldots$ & $\ldots$ & $\ldots$ & $\ldots$ & $\ldots$ & $15(6)$ & $\ldots$ & $\ldots$ \\
\hline Vicia angustifolia & $\ldots$ & $\ldots$ & $\ldots$ & $\ldots$ & $\ldots$ & $\ldots$ & $\ldots$ & $1(1)$ & $\ldots$ & $\ldots$ \\
\hline Artemisia princeps & $\ldots$ & $\ldots$ & $\ldots$ & $\ldots$ & $\ldots$ & $\ldots$ & $\ldots$ & $\ldots$ & $1(0)$ & $0(0)$ \\
\hline Gnaphalium affine & $\ldots$ & $\ldots$ & $\ldots$ & $\ldots$ & $\ldots$ & $\ldots$ & $\ldots$ & $\ldots$ & $4(2)$ & $\ldots$ \\
\hline Senecio vulgaris & $\ldots$ & $\ldots$ & $\ldots$ & $\ldots$ & $\ldots$ & $\ldots$ & $\ldots$ & $\ldots$ & $3(1)$ & $\ldots$ \\
\hline Bothriospermum tenellum & $\ldots$ & $\ldots$ & $\ldots$ & $\ldots$ & $\ldots$ & $\ldots$ & $\ldots$ & $\ldots$ & $\ldots$ & $4(2)$ \\
\hline
\end{tabular}

a Number of adult $F$. occidentalis collected. Number of viruliferous thrips, which was identified by double-antibody sandwich enzyme-linked immunosorbent assay, is indicated in parentheses.

$\mathrm{b} *=$ All fruits were decomposed completely.

c $\ldots=$ No samples were collected in the field. 
they rotted in February (Table 2). F. occidentalis (15.8 to $100 \%$ ) on the fruits were TSWV viruliferous. No fresh green pepper fruit was found after 25 February. F. occidentalis adults were captured from 12 wild weed species from 12 December to 25 March. Most samples were inhabited by viruliferous $F$. occidentalis occasionally. The proportion of viruliferous $F$. occidentalis did not decrease during the survey period, although the insects changed host plants. Similarly, a field survey in SLB showed that green pepper fruits discarded on the ground were inhabited by $F$. occidentalis until 1 March (Table 3). There were viruliferous adults of $F$. occidentalis through the winter (25.0 to $66.7 \%)$ with the tendency to decrease gradually. In this field, there were very few weeds. Adults of $F$. occidentalis were captured from four wild weed species in March. Viruliferous $F$. occidentalis was detected from $S$. aquatica only on 8 March.

In an open field (SLC), decaying green pepper fruits remained until 23 February and $F$. occidentalis adults inhabited the fruits (Table 4). The green pepper fruits were decomposed completely by 1 March. Adults of $F$. occidentalis were captured from 10 wild weed species. Many F. occi- dentalis were captured from the weeds, and 22.2 to $29.8 \%$ of the populations were viruliferous. No TSWV viruliferous thrips were found on either green pepper fruits or weeds in SLH through the winter, where TSWV had not been detected during the cultivation period in the summer (data not shown).

Transition of $F$. occidentalis populations in the field. The population analysis of $F$. occidentalis inhabiting the green pepper fruits and six weed species showed that adult and larval $F$. occidentalis inhabited green pepper fruits until 23 February (Table 5). No thrips were captured from

Table 3. Population and viruliferous proportion of adult Frankliniella occidentalis on weeds and discarded green pepper fruits in a greenhouse in Kamizono

\begin{tabular}{|c|c|c|c|c|c|c|c|}
\hline \multirow[b]{2}{*}{ Hosts } & \multicolumn{7}{|c|}{2004} \\
\hline & $1 / 9$ & $2 / 10$ & $2 / 23$ & $3 / 1$ & $3 / 8$ & $3 / 17$ & $3 / 23$ \\
\hline Discarded green pepper fruits & $5(3)^{\mathrm{a}}$ & $6(4)$ & $6(1)$ & $4(1)$ & $* \mathrm{~b}$ & $*$ & $*$ \\
\hline Stellaria aquatica & $\ldots \mathrm{c}^{\mathrm{c}}$ & $\ldots$ & $\ldots$ & $\ldots$ & $15(3)$ & $1(0)$ & $\ldots$ \\
\hline Conyza sumatrensis & $\ldots$ & $\ldots$ & $\ldots$ & $\ldots$ & $\ldots$ & $4(0)$ & $\ldots$ \\
\hline Corydalis incisa & $\ldots$ & $\ldots$ & $\ldots$ & $\ldots$ & $\ldots$ & $2(0)$ & $\ldots$ \\
\hline Lamium amplexicaule & $\ldots$ & $\ldots$ & $\ldots$ & $\ldots$ & $\ldots$ & $\ldots$ & $1(0)$ \\
\hline
\end{tabular}

a Number of adult $F$. occidentalis collected. Percentages of viruliferous thrips are indicated in parentheses.

$\mathrm{b} *=$ All fruits were decomposed completely.

c $\ldots=$ No samples were collected in the field.

Table 4. Population and viruliferous proportion of adult Frankliniella occidentalis on weeds and discarded green pepper fruits in an open field in Kokuragi

\begin{tabular}{|c|c|c|c|c|c|c|c|c|c|c|}
\hline \multirow[b]{2}{*}{ Hosts } & \multicolumn{10}{|c|}{2004} \\
\hline & $1 / 9$ & $1 / 20$ & $1 / 29$ & $2 / 23$ & $3 / 1$ & $3 / 8$ & $3 / 17$ & $3 / 23$ & $4 / 7$ & $4 / 21$ \\
\hline Discarded green pepper fruits & $2(0)^{\mathrm{a}}$ & $3(1)$ & $9(2)$ & $47(14)$ & $* \mathrm{~b}$ & * & * & $*$ & $*$ & * \\
\hline Artemisia princeps & $\ldots$ & $\ldots$ & $\ldots$ & $\ldots$ & $14(2)$ & $\ldots$ & $8(0)$ & $16(4)$ & $4(2)$ & $\ldots$ \\
\hline Vicia angustifolia & $\ldots$ & $\ldots$ & $\ldots$ & $\ldots$ & $44(5)$ & $\ldots$ & $17(5)$ & $12(3)$ & $22(4)$ & $\ldots$ \\
\hline Lamium amplexicaule & $\ldots$ & $\ldots$ & $\ldots$ & $\cdots$ & $195(25)$ & $122(26)$ & & $29(10)$ & $17(5)$ & $\ldots$ \\
\hline Viola mandshurica & $\ldots$ & $\ldots$ & $\ldots$ & $\ldots$ & $3(0)$ & $\ldots$ & $8(3)$ & $\ldots$ & $\ldots$ & $\ldots$ \\
\hline Conyza sumatrensis & $\ldots$ & $\ldots$ & $\ldots$ & $\ldots$ & $\ldots$ & $\ldots$ & $7(0)$ & $\ldots$ & $\ldots$ & $\ldots$ \\
\hline Sonchus oleraceus & $\ldots$ & $\ldots$ & $\ldots$ & $\ldots$ & $\ldots$ & $\begin{array}{l}\cdots \\
\cdots\end{array}$ & $5(0)$ & $\ldots$ & $\ldots$ & $\ldots$ \\
\hline Capsella bursa-pastoris & $\ldots$ & $\ldots$ & $\ldots$ & $\ldots$ & $\ldots$ & $\ldots$ & $35(4)$ & $14(1)$ & $\ldots$ & $\ldots$ \\
\hline Stellaria aquatica & $\ldots$ & $\ldots$ & $\ldots$ & $\ldots$ & $\ldots$ & $\ldots$ & $17(2)$ & $6(4)$ & $15(5)$ & $\ldots$ \\
\hline Veronica persica & $\ldots$ & $\ldots$ & $\ldots$ & $\ldots$ & $\ldots$ & $\ldots$ & $7(1)$ & $2(1)$ & $8(2)$ & $\ldots$ \\
\hline Trifolium repens & $\ldots$ & $\ldots$ & $\ldots$ & $\ldots$ & $\ldots$ & $\ldots$ & $\ldots$ & $\ldots$ & $\ldots$ & $56(5)$ \\
\hline
\end{tabular}

${ }^{a}$ Number of adult $F$. occidentalis collected. Percentages of viruliferous thrips are indicated in parentheses.

$\mathrm{b} *=$ All fruits were decomposed completely.

c $\ldots=$ No samples were collected in the field.

Table 5. Transition of adult and larval Frankliniella occidentalis population in an open field in Kokuragi

\begin{tabular}{|c|c|c|c|c|c|c|c|c|c|c|c|c|}
\hline \multirow[b]{2}{*}{ Hosts } & \multirow[b]{2}{*}{ Stage $^{\mathbf{a}}$} & \multicolumn{11}{|c|}{2004} \\
\hline & & $1 / 9$ & $1 / 20$ & $1 / 29$ & $2 / 10$ & $2 / 23$ & $3 / 1$ & $3 / 8$ & $3 / 17$ & $3 / 23$ & $4 / 7$ & $4 / 21$ \\
\hline \multirow[t]{2}{*}{ Discarded green pepper fruits } & Adult & $0.1^{\mathrm{b}}$ & 0.3 & 0.7 & 1.6 & 1.5 & 0 & $\ldots{ }^{c}$ & $\ldots$ & $\ldots$ & $\ldots$ & $\ldots$ \\
\hline & Larvae & 1.4 & 1.4 & 1.0 & 2.5 & 0.1 & 0 & $\ldots$ & $\ldots$ & $\ldots$ & $\ldots$ & $\ldots$ \\
\hline \multirow[t]{2}{*}{ Lamium amplexicaule } & Adult & $\ldots$ & $\ldots$ & $\ldots$ & 0 & 2.7 & 4.9 & 2.6 & 4.2 & 3.9 & 0.5 & 0 \\
\hline & Larvae & $\ldots$ & $\ldots$ & $\ldots$ & 0 & 0 & 0 & 0.1 & 2.8 & 0.5 & 0.2 & 0 \\
\hline \multirow[t]{2}{*}{ Vicia angustifoli } & Adult & $\ldots$ & $\ldots$ & $\ldots$ & 0 & 0.3 & 0 & 0 & 5.7 & 2.0 & 2.2 & 0 \\
\hline & Larvae & $\ldots$ & $\ldots$ & $\ldots$ & 0 & 0 & 0 & 0 & 4.0 & 0 & 2.7 & 0 \\
\hline \multirow[t]{2}{*}{ Artemisia princeps } & Adult & $\ldots$ & $\ldots$ & $\ldots$ & 0 & 0.6 & 0 & 0 & 1.5 & 2.3 & 0.3 & 0 \\
\hline & Larvae & $\ldots$ & $\ldots$ & $\ldots$ & 0 & 0 & 0 & 0 & 2.8 & 3.6 & 2.3 & 0 \\
\hline \multirow[t]{2}{*}{ Veronica persica } & Adult & $\ldots$ & $\ldots$ & $\ldots$ & $\ldots$ & 0.3 & 0 & 0 & 0.7 & 0.2 & 0.8 & 0 \\
\hline & Larvae & $\ldots$ & $\ldots$ & $\ldots$ & $\ldots$ & 0 & 0 & 0 & 1.4 & 2.4 & 6.2 & 0 \\
\hline \multirow[t]{2}{*}{ Stellaria aquatica } & Adult & $\ldots$ & $\ldots$ & $\ldots$ & $\ldots$ & $\ldots$ & 0 & 0 & 0.9 & 2.6 & 0 & 0 \\
\hline & Larvae & $\ldots$ & $\ldots$ & $\ldots$ & $\ldots$ & $\ldots$ & 0 & 0 & 3.0 & 5.8 & 0.3 & 0 \\
\hline \multirow[t]{2}{*}{ Capsella bursa-pastoris } & Adult & $\ldots$ & $\ldots$ & $\ldots$ & $\ldots$ & $\ldots$ & $\ldots$ & 0 & 3.5 & 1.4 & 0.7 & 0 \\
\hline & Larvae & $\ldots$ & $\ldots$ & $\ldots$ & $\ldots$ & $\ldots$ & $\ldots$ & 0 & 2.3 & 0.3 & 1.3 & 0 \\
\hline \multirow[t]{2}{*}{ Trifolium repens } & Adult & $\ldots$ & $\ldots$ & $\ldots$ & $\ldots$ & $\ldots$ & $\ldots$ & $\ldots$ & $\ldots$ & 0 & 1.2 & 2.9 \\
\hline & Larvae & $\ldots$ & $\ldots$ & $\ldots$ & $\ldots$ & $\ldots$ & $\ldots$ & $\ldots$ & $\ldots$ & 0 & 1.0 & 0.3 \\
\hline
\end{tabular}

${ }^{a}$ Larvae were bred with broad beans to identify as F. occidentalis.

${ }^{\mathrm{b}}$ Average number of thrips captured from a sample.

c $\ldots=$ No samples were collected in the field. 
weeds until 10 February. As the weeds grew, $F$. occidentalis started to be detected from weeds. $F$. occidentalis adults were found mainly on Lamium amplexicaule but also Vicia angustifolia, Artemisia princeps, and Veronica persica. However, larvae did not appear until 8 March. After 17 March, adult and larval $F$. occidentalis spread on S. aquatica and Capsella bursa-pastoris. F. occidentalis was found on Trifolium repens on 21 April as the flowers bloomed.

Survey of flying viruliferous $F$. occidentalis using sticky traps. Sticky traps placed in SLC first captured $F$. occidentalis adults on 10 February. The number of $F$. occidentalis captured on the sticky traps peaked around 1 March and decreased gradually thereafter (Fig. 1). Percentages of viruliferous $F$. occidentalis did not significantly change (Fisher's exact test, $P=$ 0.8094) while being trapped from 10 February to 7 April.

TSWV infection in seedling traps. On 18 May, 6 of 10 green pepper seedlings planted in SLC showed necrotic ringspot and yellowing, which are typical symptoms of TSWV infection. TSWV was detected from the symptomatic leaves by DAS-ELISA.

\section{DISCUSSION}

In this study, we evaluated populations of virulferous $F$. occidentalis and TSWVinfected weeds in TSWV-affected green pepper fields to reveal the infection source of TSWV in the winter. Bungo-Ohno City is located in the center of Kyusyu, Japan. The climate is relatively mild and it rarely snows during the winter. In this area, sweet potato, taro, and tobacco are grown in fields and ornamental flowers, green pepper, and strawberry are grown in greenhouses. Green peppers are usually grown from March to November, and any crops that could be infected with TSWV are not grown near the greenhouses when green pepper seedlings are planted in the early spring. However, green pepper plants, which were confirmed negative in the nursery, were infected with TSWV as soon as they were transplanted to the greenhouses.

Crude sap from some weeds gives a false positive reaction in ELISA. To avoid this problem, RT-PCR, which is less likely to give a false positive reaction, was conducted to test for TSWV infection in weeds in this study. Among a few weed species found in the greenhouses in the winter, some species were infected with TSWV. Comparatively, a high proportion of $S$. aquatica was infected. S. media was often reported as a reservoir of TSWV $(2,6,14,15)$. However, infection of $S$. aquatica is considered secondary in this area because $S$. aquatica appears in the fields in late February or early March. Incidence of infection in other weed species was low. The results suggest that weeds represent only a minor source in this area. On the other hand, green pepper fruits discarded in the greenhouses and open fields were frequently infected with TSWV. Interestingly, TSWV was detected in the discarded green pepper fruits until March, even though the fruits matured and turned red. TSWV was also detected in $F$. occidentalis collected from the green pepper fruits. Larvae of $F$. occidentalis collected from these fruits were TSWV positive after being grown to adults by feeding on healthy broad beans (data not shown). This suggests that $F$. occidentalis feeding on the TSWV-infected green pepper fruits acquired and could transmit TSWV to green pepper seedlings.

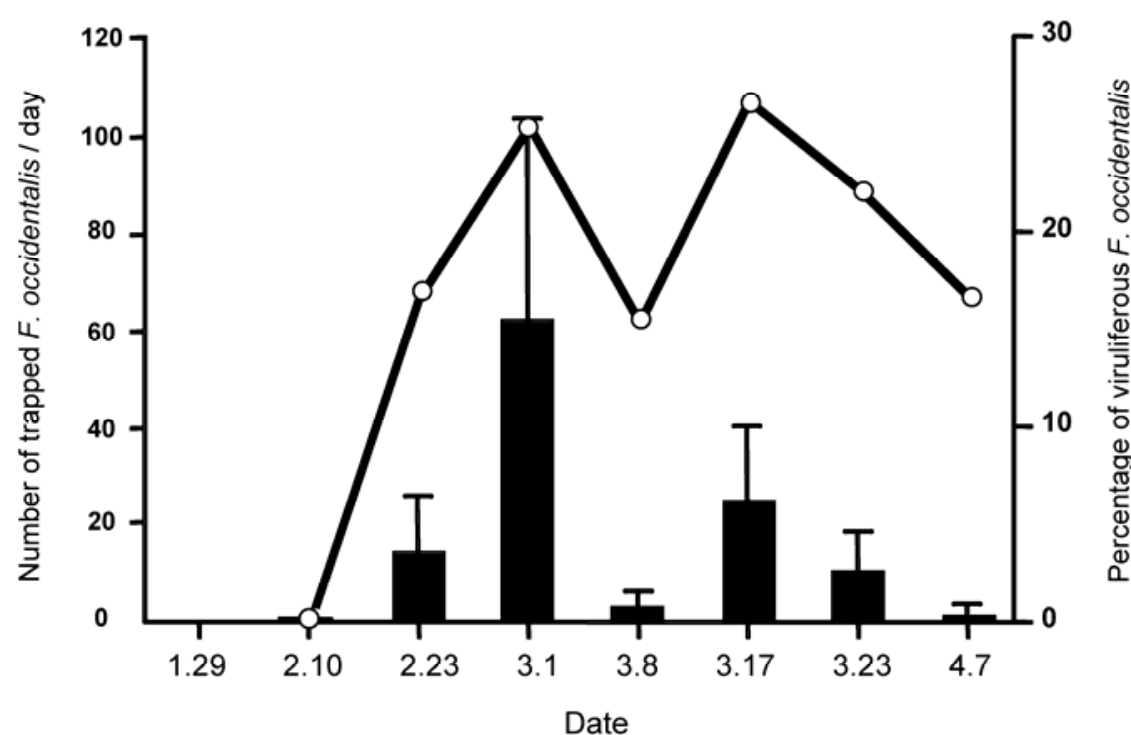

Fig. 1. Transition of number of Frankliniella occidentalis and percentage of viruliferous individuals captured with sticky traps. Columns indicate the number of insects captured on the traps (left scale). Values are the average of three traps, and the vertical bar above each column indicates standard deviation. The solid line indicates percentage of viruliferous $F$. occidentalis (right scale).
Population analysis showed that $F$. occidentalis primarily inhabited and reproduced on the green pepper fruits and moved to L. amplexicaule when the fruits rotted and subsequently spread to other weed species as young shoots or flowers appeared. The flying activity level of $F$. occidentalis rose in late February and more than $15.4 \%$ of $F$. occidentalis was viruliferous. Seedling traps suggested that the viruliferous $F$. occidentalis transmitted TSWV to green pepper plants in this area. Several weed species were inhabited by $F$. occidentalis in greenhouses and fields. However, rare TSWV infections of weeds in this area suggest movement of the viruliferous thrips from TSWV-infected green pepper to weeds. Another bit of circumstantial evidence is that TSWV was not detected from some host plants despite the presence of viruliferous $F$. occidentalis (data not shown). Although some weeds were inhabited by $F$. occidentalis during the winter, as reported previously $(11,13,14), F$. occidentalis showed clear preference to green pepper fruits until the fruits rotted. Maris et al. suggested that TSWV-infected plants significantly attract $F$. occidentalis (12). The preference for TSWV-infected green pepper fruits was so strong that the population of $F$. occidentalis in this area might be biased. Further study will be needed to clarify the impact to the population.

In this study, we concluded that TSWVinfected green pepper fruits discarded in greenhouses and fields are the major source of infection in this area. The occurrence of TSWV disease in Bungo-Ohno City drastically fell during 2005 after green pepper fruits of the previous season were entirely removed from TSWVaffected greenhouses (data not shown). This study shows that we can terminate the infection cycle if we eliminate the source of TSWV infection.

\section{ACKNOWLEDGMENTS}

The authors thank Tamito Sakurai, National Agricultural Research Center for Tohoku region, Haruki Katayama, Shizuaka Agricultural Experiment Station and Hanu R. Pappu, Washington State University for their helpful suggestions.

\section{LITERATURE CITED}

1. Bautista, R. C., Mau, R. F. L., Cho, J. J., and Custer, D. M. 1995. Potential of tomato spotted wilt tospovirus plant hosts in Hawaii as virus reservoirs for transmission by Frankliniella occidentalis (Thysanoptera: Thripidae) Phytopathology 85:953-958.

2. Bitterlich, I., and MacDonald, L. S. 1993 . The prevalence of tomato spotted wilt virus in weeds and crops in southwestern British Columbia. Can. Plant Dis. Surv. 73:137-142.

3. Brittlebank, C. C. 1919. Tomato diseases. J. Agric. Vic. 17:213-235

4. Chamberlin, J. R., Todd, J. W., Culbreath, A. K., Johnson, W. C., III, and Demski, J. W. 1993. Post-harvest management of tobacco thrips (Thysanoptera: Thripidae) overwintering in peanut fields. J. Entomol Sci. 28:33-446.

5. Cho, K., Eckel, C. S., Walgenbach, J. F., and Kennedy, G. G. 1995. Overwintering of thrips 
(Tysanoptera:Thripidae) in North Carolina. Envrion. Entomol. 24:58-67.

6. Groves, R. L., Walgenbach, J. F., Moyer, J.W., and Kennedy, G. G. 2001 Overwintering of Frankliniella fusca (Thysanoptera: Thripidae) on winter annual weeds infected with Tomato spotted wilt virus and patterns of virus movement between susceptible weed hosts. Phytopathology 91:891-899.

7. Katayama, H., and Ikeda, F. 1995. Overwintering of western flower thrips Frankliniella occidentalls Pergande in the western region of Shizuoka Prefecture. (In Japanese.) B. Shizuoka Agric. Exp. Stn. 40:63-73.

8. Katayama, H. 1997. Effect of temperature on development and oviposition of western flower thrips Frankliniella occidentalis (Pergande). (In Japanese.) Jpn. J. Appl. Entomol. Zool. 41:225-231.

9. Kawano, T., Takahashi, K., Takahashi, Y., Tairako, K., Tsukamoto, S., Kobayashi, Y., and Honda, Y. 2001. Spotted wilt disease of verbena, Madagascar periwinkle and impatienses caused by Tomato spotted wilt virus. (In Japanese.) Ann. Rep. Kanto-Tosan Plant Prot.
Soc. 48:101-104.

10. Kobatake, H. 1984. Ecology and control of spotted wilt disease of tomato in Nara Prefecture. (In Japanese) Proc. Kansai Plant Prot. Soc. 26:23-28.

11. Latham, L. J., and Jones, R. A. C. 1997. Occurrence of tomato spotted wilt tospovirus in native flora, weeds, and horticultural crops. Aust. J. Agr. Res. 48:359-369.

12. Maris, P. C., Joosten, N. N., Goldbach, R. W., and Peters, D. 2004. Tomato spotted wilt virus infection improves host suitability for its vector Frankliniella occidentalis. Phytopathology 94:706-711

13. McPherson, R. M., Beshear, R. J., Johnson, W. C. III, Martinez-Ochoa, N., and Wells, M. L. 2003. Winter and early-spring survey of thrips vectors and host plants of tomato spotted wilt Tospovirus in and near a fluecured tobacco farmscape. J Entomol. Sci. 38:660-668.

14. Mertelik, J., Gotzova, B., and Mokra, V. 1996. Epidemiological aspects of tomato spotted wilt virus infection in the Czech Republic. Acta Hortic. 432:368-375.
15. Mertelík, J., and Mokrá, V. 1998. Tomato spotted wilt virus in ornamental plants, vegetables and weeds in the Czech Republic. Acta Virol. 42:347-351.

16. Mound, L. A. 1997. The Thysanoptera vector species of tospoviruses. Acta Hortic. 431:298 306.

17. Moyer, J. W. 1999. Tospoviruses (Bunyaviridae). Pages 1803-1807 in: Encyclopedia of Virology. 3rd ed. A. Granoff and R. G. Webster, eds. Academic Press, San Diego.

18. Murai, T., and Ishii, T. 1982. Simple rearing method for flower thrips (Thysanoptera: Thripidae) on pollen. (In Japanese, with English summary.) Jpn. J. Appl. Entomol. Zool. 26:149-154.

19. Samuel, G., Bald, J. G., and Pitman, H. A 1930. Investigations on 'spotted wilt' of tomatoes. Aust. Commonw. Counc. Sci. Ind Res. Bull. 44.

20. Suetsugu, T. 1969. Tomato spotted wilt virus detected from imported Dahlia in postentry quarantine. (In Japanese, with English summary.) Res. Bull. Plant Prot. Serv. Jpn. 7:50 56. 